\title{
Retinoic Acid Correlates with Reduced Serum IL-10 And TGF- $\beta$ in Allergic Rhinitis
}

\author{
Akram Davoodi ${ }^{1}$, Ramin Lotfi ${ }^{2}$, Seyed Hamidreza Mortazavi ${ }^{3}$, \\ Ali Gorgin Karaji ${ }^{4}$, Alireza Rezaiemanesh ${ }^{4}$, Farhad Salari*4
}

\begin{abstract}
Background: Retinoic acid (RA) plays a key role in naïve $\mathrm{T}$ cell differentiation into $\mathrm{FOXP}^{+}$Treg cell in the respiratory airways. The present study aims to investigate RA and Treg-related cytokine serum levels, salivary IgA levels, FOXP3 and IL-4 gene expression, and the relationships between RA serum levels and Treg-related cytokines in allergic rhinitis (AR) patients and healthy controls.

Methods: Salivary IgA and serum IgE, RA, IL-10, and TGF- $\beta$ concentrations were measured by ELISA in 37 AR patients and 30 age- and sex-matched healthy controls.

Results: IL-10 and TGF- $\beta$ concentrations were significantly less in AR patients than in healthy controls ( $\mathrm{p}<$ 0.01 and $\mathrm{P}<0.0001$, respectively). Salivary IgA was significantly greater in patients than in controls $(\mathrm{p}<0.05)$. RA was not significantly different between patients and controls ( $p>0.05)$; however, a significant positive correlation was found between serum RA and both IL-10 and TGF- $\beta$ in AR patients.
\end{abstract}

Conclusions: Our data suggest that RA may influence AR risk via affecting the TGF- $\beta$ and IL-10 production.

Keywords: Allergic Rhinitis, Interleukin-10, Obesity, Retinoic Acid, Transforming Growth Factor- $\beta$.

\section{Introduction}

Allergic rhinitis (AR) is an upper airway inflammatory disease with a growing prevalence rate over the past 30 years (1). T helper 2 (TH2) cells and their cytokines, including interleukin (IL)-4, IL-5, and IL-13, play a central role in the pathogenesis of AR. Furthermore, many underlying factors, including genetic background, IgE serum concentration greater than $100 \mathrm{IU} / \mathrm{ml}$ before the age of 6 years, stress, nutrition, and vitamins $A$ and $D$ deficiencies are recognized as risk factors for $\operatorname{AR}(2,3)$.

Retinoic acid (RA), an active vitamin A metabolite, plays a critical role in the immune system. For example, RA is known to influence the development, maintenance, differentiation, and regeneration of lung epithelial cells (4). In addition, it has been shown that a subset of
$\mathrm{CD}_{103}{ }^{+}$dendritic cells (DCs), which secrete transforming growth factor- $\beta$ (TGF- $\beta$ ) and RA in the lung mucosa, is required for $\mathrm{T}$ cell differentiation into forkhead box $\mathrm{P}^{+}\left(\mathrm{FOXP}^{+}\right)$ regulatory $\mathrm{T}$ cells (Treg cells) (5). Also, considerable evidence suggests that $\mathrm{FOXP}^{+}$Treg cells play a major role in controlling, and ultimately inhibiting, allergic diseases $(6,7)$. Notably, RA is critical for the generation of $\mathrm{B}$ cells secreting immunoglobulin $\mathrm{A}$ ( $\operatorname{IgA}$ ), which is the dominant Ig class in healthy respiratory tract mucosa, and seems to be the most critical Ig for mucosal defense (8). Deficiency or defect of IgA causes a change in the mucosal defense and prepares the conditions for increased allergen penetration into the tissue and the onset of allergy $(9,10)$. Besides, RA suppresses eosinophil and 
basophil differentiation from bone marrow precursors (11), most likely by downregulating IL-5 receptor (12) expression and preventing mitogen-induced proliferation and IL-4-mediated IgE production in murine splenocytes (13). Recent studies have shown that naïve $\mathrm{T}$ cell differentiation into $\mathrm{TH} 1$ and $\mathrm{TH} 2$ cells is regulated by RA (14). However, the results of various studies are controversial. On the one hand, it has been reported that all-trans RA supplementation in vitamin A-deficient mice inhibited interferon (IFN)- $\gamma$ and IL-12 transcription and supported $\mathrm{TH} 2$ cell differentiation and growth (15), while in contrast, RA was recently found to exert an anti-allergic effect by inhibiting $\mathrm{TH} 2$ responses and inducing Treg cell differentiation (16).

In this study, we measured the serum concentrations of RA, IgE, and the Treg-related cytokines IL-10 and TGF- $\beta$, salivary IgA, FOXP3 and $\mathrm{IL}-4$ gene expression, and the relationships between RA serum levels and Treg-related cytokines in AR patients and healthy controls.

\section{Materials and methods Subjects}

Allergic rhinitis patients were recruited from outpatients attending the Allergy Clinic of the Mohammad Kermanshahi Hospital in Kermanshah, Iran. All patients were diagnosed by physicians based on the Practical Guideline for the Management of Allergic Rhinitis (17). The control group was selected from healthy individuals with no chronic inflammatory diseases. Written informed consent was obtained from all subjects. Body mass index (BMI) was calculated for each subject as weight in kilograms divided by the squared height in meters $(\mathrm{kg} / \mathrm{m} 2)$. Subjects with BMIs $\geq 30$ were classified as obese. Characteristics of $\mathrm{AR}$ patients and healthy controls are described in Table 1.

Table 1. Demographic data of AR patients and healthy control subjects.

\begin{tabular}{lll}
\hline Group & Allergic rhinitis & Control \\
\hline Number & 37 & 30 \\
Sex (Female/Male) & $24 / 13$ & $20 / 10$ \\
Average age & $35.18 \pm 1.74$ & $34.96 \pm 2.33$ \\
Average disease duration & Six years & - \\
History of asthma & - & - \\
Smoking $(\%)$ & 21.6 & - \\
BMI ${ }^{*}(\%)$ & & \\
Normal & 48.3 & 66.6 \\
Overweight & 38.7 & 18.59 \\
Obese & 12.9 & 14.81 \\
* BMI: Body mass index & &
\end{tabular}

\section{Sample collection}

Ten $\mathrm{ml}$ of fresh whole blood were drawn by venipuncture. Serum was isolated from $7.5 \mathrm{ml}$ of the blood sample. To extract total RNA, $2.5 \mathrm{ml}$ of the blood sample was aliquoted into tubes containing ethylenediamine tetraacetic acid (EDTA). Saliva samples were collected from all participants. For each participant, a peripheral blood smear was prepared and the number and percentage of eosinophils determined manually using an optical microscope.

\section{RNA isolation, $c D N A$ synthesis, and qRT-PCR}

Total RNA was extracted from blood using an RNA isolation kit (Favorgen Biotech CORP kit, Taiwan) according to the manufacturer's instructions. cDNA was synthesized with an equal amount of total RNA using a cDNA synthesis kit (Favorgen Biotech CORP kit, Taiwan) with random primers according to the manufacturer's protocol. Real-time PCR was performed using the Light Cycler 96 (Roche, Germany) and SYBR Green (Ampliqon, 
Odense, Denmark) master mix. Primers were designed with Beacon Designer ${ }^{\mathrm{TM}}$ Software (Primer Biosoft, USA). Primer sequences for FOXP3 were: FOXP3 forward: 5'AAGAGAGAGGTCTGCGGCTTC-3' and FOXP3 reverse: 5'CAGGCTTGGTGAAGTGGACTG-3'. Primer sequences for IL-4 were: IL-4 forward: 5'CACGGACACAAGTGCGATA-3' and IL-4 reverse: 5'-GCGAGTGTCCTTCTCATGGT-3'. The values were normalized based on the expression of GAPDH as a housekeeping gene using the following primers: GAPDH forward 5'-GACCCCTTCATTGACCTCAAC-3' and GADPH reverse 5'GATCTCGCTCCTGGAAGATG-3'. The relative gene expression differences between controls and patients were determined using the Pfaffl method $\left(\mathrm{R}=\left(\mathrm{E}_{\text {target }}\right) \Delta \mathrm{Ct}\right.$ target (control-sample)/ $\left.\left(\mathrm{E}_{\mathrm{Ref}}\right)^{\Delta \mathrm{Ct} \operatorname{Ref}(\text { control-sample) }}\right)$.

\section{Serum IL-10, TGF- $\beta$, total IgE, and retinoic} acid, and salivary IgA concentrations

To measure serum IL-10, TGF- $\beta$, total IgE, and retinoic acid, and salivary $\operatorname{IgA}$ concentrations, enzyme-linked immunosorbent assays (ELISAs) were performed using commercial kits according to the manufacturer's recommendations (Eastbiopharm kit, China).

\section{Statistical analysis}

Statistically significant differences between patients and controls were determined by the nonparametric Mann-Whitney U-test. The correlations were determined using Spearman rank correlation analysis. Analysis of data was conducted by SPSS software version 18 for Windows (IBM Corp., Armonk, N.Y., USA). p values $<0.05$ were considered statistically significant. All data are expressed as means \pm SEMs.

\section{Results}

Serum IL-10, TGF- $\beta$, total IgE, and retinoic acid, and salivary IgA concentrations

Serum TGF- $\beta$ (Fig. 1A) and IL-10 (Fig. 1B) were significantly less, while salivary IgA (Fig. 1C) was significantly greater, in patients than in controls. Total IgE was greater (Fig. 1D), and RA was less (Fig. 1E), in AR patients than in controls; however, these differences were not statistically significant.
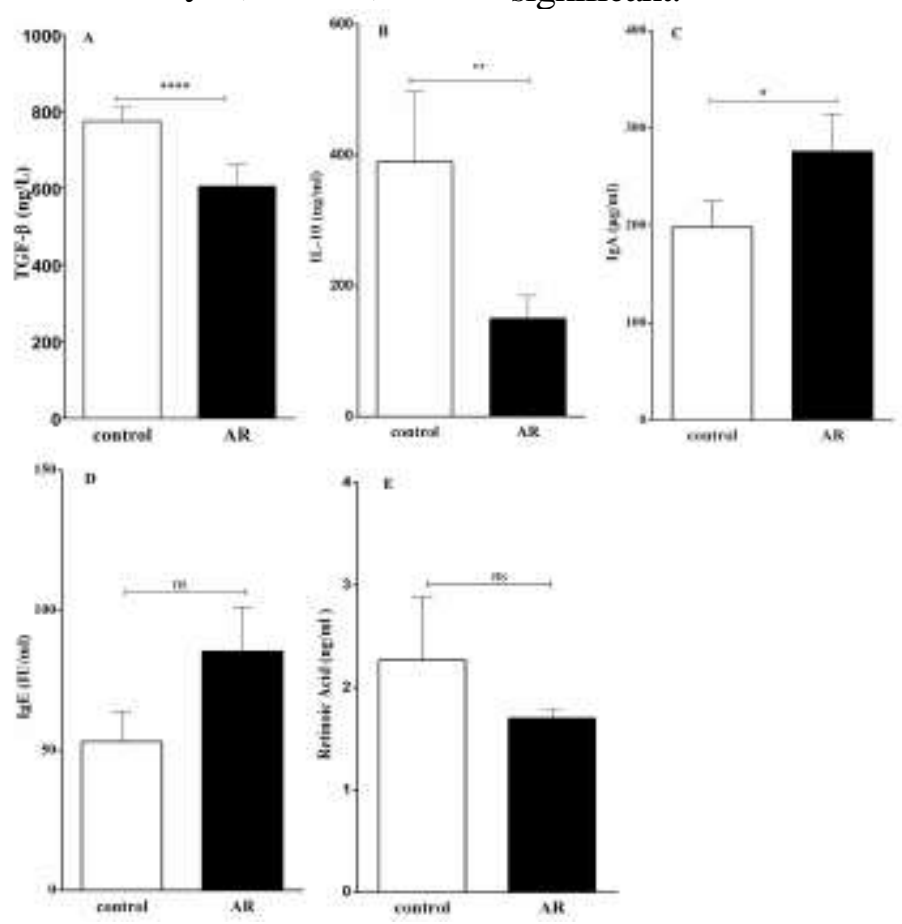

Fig. 1. Serum TGF- $\beta$ and IL-10, salivary IgA, total IgE, and retinoic acid concentrations in healthy controls and allergic rhinitis (AR) patients. For serum assays, whole blood was collected from each subject and serum was isolated and analyzed by ELISA. Saliva was collected and analyzed for the IgA ELISA. Significantly less TGF- $\beta$ (A) and IL-10 (B) were present in AR patients than healthy controls. Salivary IgA was significantly greater in AR patients than healthy controls (C). Neither $\operatorname{IgE}(\mathrm{D})$ nor retinoic acid (E) differed significantly between the two groups. Results are shown as means \pm SEMs; ${ }^{*} p<0.05, * * p<0.01, * * * * p<0.0001$ and ns: not significant; AR: allergic rhinitis and RA: retinoic acid. 
FOXP3 and IL-4 mRNA expression

FOXP3 mRNA expression did not differ significantly between the two groups (Fig. 2A); however, IL-4 mRNA expression was significantly greater in patients than in controls (Fig. 2B).

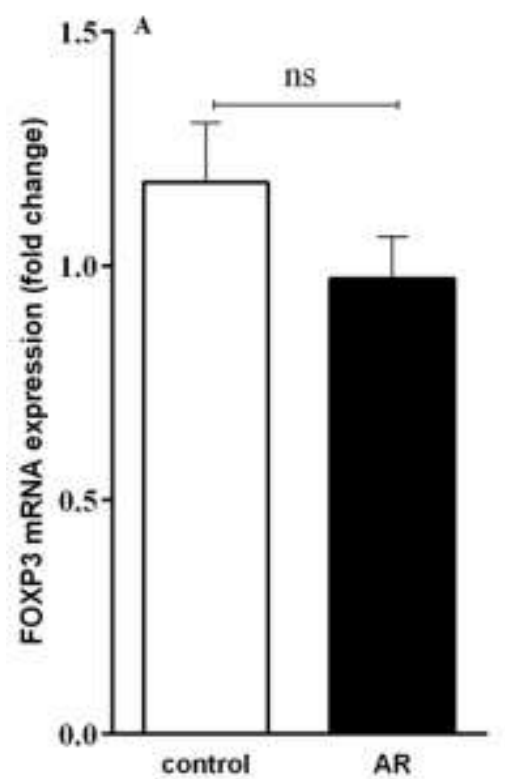

\section{Percentage of peripheral blood eosinophils}

The percentages of peripheral blood eosinophils in patients with $\mathrm{AR}$ and controls were determined. The percentage was significantly greater in the patients with AR than in controls (Fig. 3).

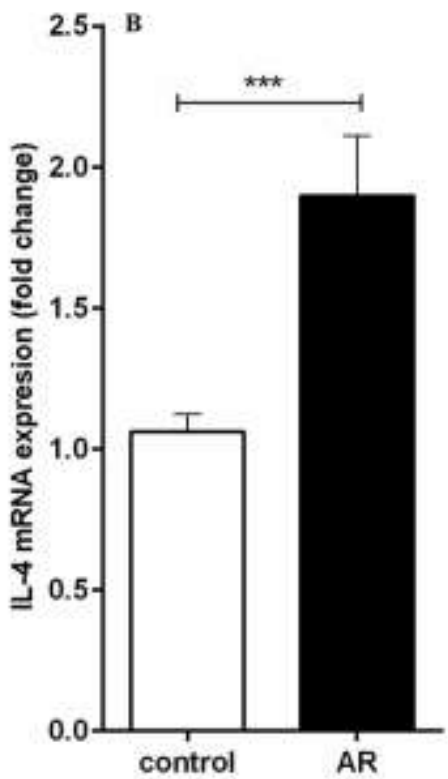

Fig. 2. FOXP3 and IL-4 mRNA expression in healthy controls and allergic rhinitis (AR) patients. Total RNA was extracted from blood using an RNA isolation kit, cDNA was synthesized using random primers, and real-time PCR was performed. The values were normalized against GAPDH. (A) FOXP3 mRNA expression in healthy controls and AR patients. No significant difference in FOXP3 mRNA expression was observed between the two groups. (B) IL-4 mRNA expression in healthy controls and AR patients. IL-4 expression was significantly greater in patients than controls. Results are shown as means \pm SEMs; ns: not significant; $* *$ p $<0.001$; AR: allergic rhinitis.

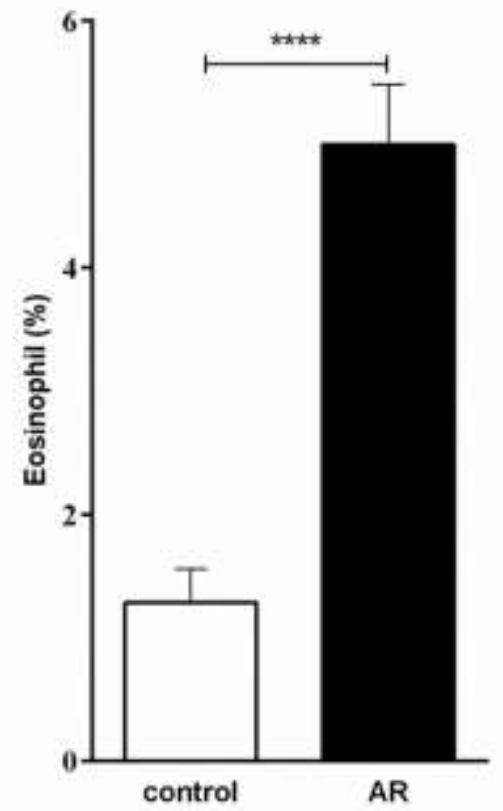

Fig. 3. Percentage of peripheral blood eosinophils in healthy controls and allergic rhinitis (AR) patients. For each participant, a peripheral blood smear was prepared and the number and percentage of eosinophils determined manually using an optical microscope. The percentage of eosinophils was significantly greater in AR patients than controls. Results are shown as means $\pm \mathrm{SEMs}$; ****p<0.0001; AR: allergic rhinitis. 


\section{Correlations analysis}

Spearman correlation analysis for RA, TGF- $\beta$, and IL-10 serum levels demonstrated a significant positive correlation $(\mathrm{p}=0.002, \mathrm{r}=0.5$ and $\mathrm{p}<0.0001, \mathrm{r}=0.6$, respectively) in both $\mathrm{AR}$ and control groups (data are shown for $A R$
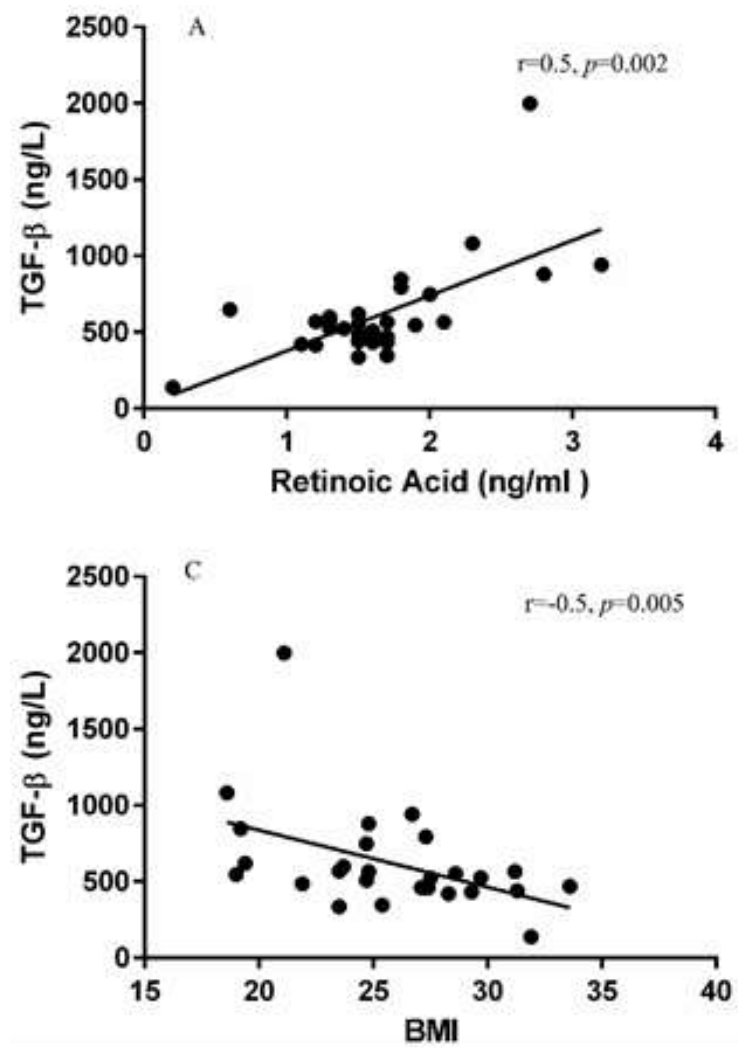

only) (Figs. 4A and 4B). In addition, a significant inverse correlation was found between BMI and both serum TGF- $\beta$ and RA levels in the AR patients $(\mathrm{p}=0.005, \mathrm{r}=-0.5$, and $\mathrm{p}=0.04, \mathrm{r}=-0.3$, respectively) (Figs. $4 \mathrm{C}$ and 4D).

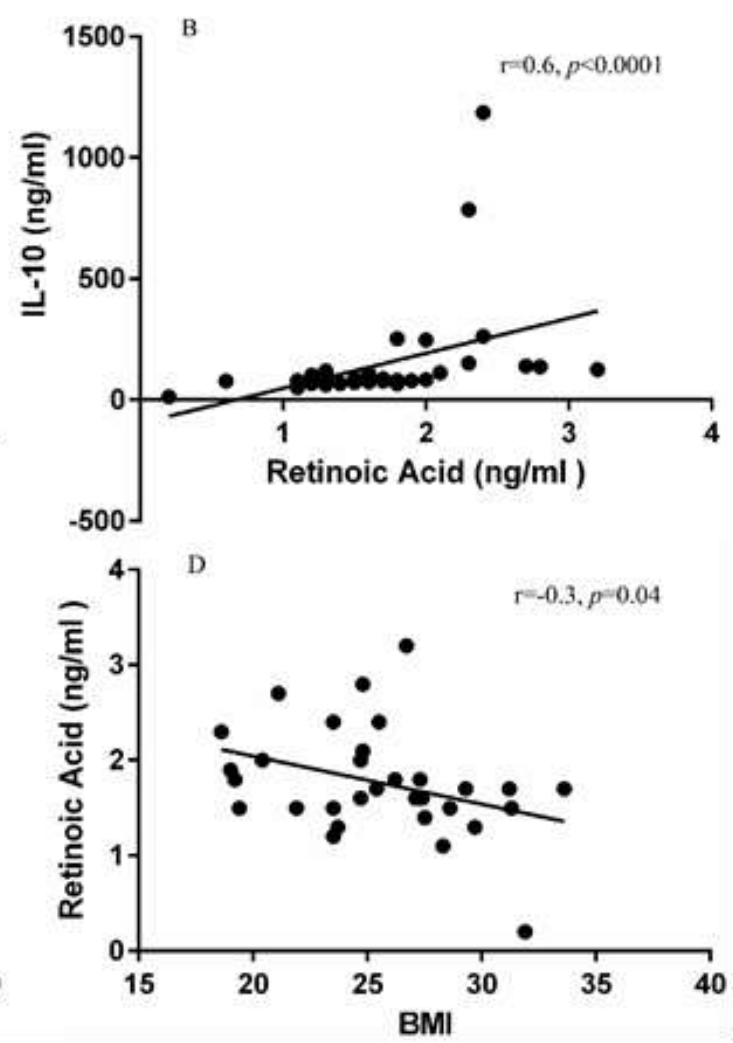

Fig. 4. Correlation analyses. Correlations were determined using the Spearman rank correlation analysis. Significant positive correlations were seen between serum RA and both TGF- $\beta$ (A) and IL-10 (B) in allergic rhinitis (AR) patients and controls (not shown). Significant negative correlations were seen between BMI and both TGF- $\beta$ (C) and retinoic acid (D) in the AR patients. RA: retinoic acid; BMI: body mass index.

\section{Discussion}

Allergic rhinitis is well known as a Th2 immunemediated disorder. In addition, considerable evidence indicates an important role for Treg cells (Tregs) in controlling and inhibiting allergic diseases. Studies have shown that the number or function of Tregs is impaired or altered in allergic patients (18-20). Although the findings in this context are controversial, studies have shown that naive $\mathrm{T}$ cell differentiation into $\mathrm{TH} 1$, TH2, and Treg cells could be regulated by RA (14-16, 21). This study aimed to address the role of RA in the development of AR.

Studies have shown that the presence of a subset of $\mathrm{CD} 103^{+}$DCs secreting TGF- $\beta$ and sufficient amounts of RA in the intestinal and pulmonary mucosa can induce differentiation of T cells into FOXP3 ${ }^{+}$Treg cells (5). Despite this evidence, in vitro and in vivo studies have shown that RA reduces TH1 and increases TH2 immune responses $(22,23)$. Some studies in the United States and Sweden have shown that vitamin A supplementation in the first few months of life increases asthma risk and skews the immune response toward $\mathrm{TH} 2$ cells $(24,25)$. In the current study, we found less serum RA in patients than in healthy controls; however, this difference was not significant. In addition to significantly greater IL-4 mRNA expression, our study also showed less, but not significantly so, FOXP3 mRNA expression in AR patients than 
in controls. Furthermore, both IL-10 and TGF- $\beta$ were significantly lower in the sera of AR patients than in controls, and a significant positive correlation was found between serum RA and both IL-10 and TGF- $\beta$ in AR patients.

Previous studies showed that RA is also effective in the synthesis of secretory $\operatorname{IgA}(\operatorname{sg} \mathrm{A})$, which plays an important role in mucosal defense (8). Some researchers believe that $\operatorname{IgA}$ deficiency or defect causes change in the mucosal defense and prepares the background for increased allergen penetration into the tissue and the onset of allergy $(9,10)$. A clear correlation exists between reduced $\operatorname{IgA}$ and atopic eczema (26). Furthermore, reduced sIgA has been reported in asthma patients (27). Additionally, high $\operatorname{sgA}$ seems to protect children from the onset of allergic symptoms during the first two years of life $(28,29)$, and allergen-specific sIgA deficiency was found to be associated with an increased risk for allergic diseases (30). Despite this evidence, other studies have not supported these findings $(31,32)$. In our study, sIgA was significantly greater in $\mathrm{AR}$ patients than in controls; however, this increase appears to contradict other findings, along with decreased serum RA. Studies have shown that IL-4, which activates, propagates, and protects B cells against apoptosis (33), also regulates IgA production (34). Therefore, IL-4 can not only increase $\operatorname{IgE}$ but can also enhance $\operatorname{sgA}$ production in allergic patients (35). Interestingly, in the present study, IL-4 expression was significantly greater in AR patients than in controls. On the other hand, allergen-specific SIgA is not always associated with tolerance induction in animal models of allergy. Indeed, high sIgA levels can be present in susceptible animals without playing a protective role (36). Thus, these contradictory results cause doubt concerning the protective role of SIgA in allergy.

In our study, IgE concentrations did not differ significantly between patients and controls; however, the eosinophil count was significantly greater in patients. Nevertheless, no significant correlation was seen between the peripheral blood eosinophil count and serum IgE. Serum IgE increases in more than $90 \%$ of patients with AR. Although elevated IgE is often a factor indicating the presence of allergic disease, $\operatorname{IgE}$ titers can also increase in parasitic infections in the absence of allergy. In addition, a low IgE titer with apparent allergy symptoms is not unusual (37). In this study, we examined peripheral blood eosinophils, but according to some studies, nasal smear eosinophils display the best correlation with clinical and immunological parameters in $\operatorname{AR}(37,38)$. It has also been suggested that $\operatorname{IgE}$ measurements and nasal eosinophil counts should be performed simultaneously (39).

According to the increased prevalence of both obesity and allergic disorders worldwide, many studies have evaluated the association between obesity and allergic diseases and asthma. Strong evidence supports an association between obesity and asthma, especially in females (40, 41). While some studies have demonstrated an increased risk for AR among overweight or obese individuals $(42,43)$, others have found no clear, and in some cases negative, correlation between the two $(41,44,45)$. Notably, age and gender are influenced when the relationship between allergic disease and obesity in children and adults is examined $(41,42)$. In the present study, we found no association between obesity and AR (data not shown). However, significant inverse correlations between BMI and serum levels of both TGF- $\beta$ and RA were observed.

In conclusion, this study found that AR patients had lower, but not significantly lower, serum RA than healthy controls. Nonetheless, being a significant positive correlation between RA and both TGF- $\beta$ and IL-10 levels in the sera of patients suggests that RA may influence the risk of AR via affecting the generation of TGF- $\beta$ and IL-10 cytokines. Further studies with larger populations are needed to define relationships between RA and AR.

\section{Acknowledgements}

The authors thank the participants for their enthusiastic collaboration. The authors also gratefully acknowledge the Research Council of Kermanshah University of Medical Sciences for financial support (Grant Number: 96125). None of the authors has any potential financial conflicts of interest related to this manuscript. 


\section{References}

1. Chong SN, Chew FT. Epidemiology of allergic rhinitis and associated risk factors in Asia. World Allergy Organ J. 2018;11(1):17.

2. Wallace DV, Dykewicz MS, Bernstein DI, Blessing-Moore J, Cox L, Khan DA, et al. The diagnosis and management of rhinitis: an updated practice parameter. J Allergy Clin Immunol. 2008;122(2 Suppl):S1-84.

3. Shirkani A, Mansouri A, Farid Hosseini R, Jabbari Azad F, Alsadat Mahmoudian R, Montazer $\mathrm{M}$, et al. The Role of Interleukin-4 and 13 Gene Polymorphisms in Allergic Rhinitis: A Case Control Study. Rep Biochem Mol Biol. 2019;8(2):111-118.

4. Gray T, Koo J-S, Nettesheim P. Regulation of mucous differentiation and mucin gene expression in the tracheobronchial epithelium. Toxicology. 2001;160(1-3):35-46.

5. Weaver CT, Hatton RD. Interplay between the T H 17 and T Reg cell lineages: a (co-) evolutionary perspective. Nat Rev Immunol. 2009;9(12):883-9.

6. Strauss L, Bergmann C, Szczepanski M, Gooding W, Johnson JT, Whiteside TL. A unique subset of CD4+ CD25highFoxp3+ $\mathrm{T}$ cells secreting interleukin-10 and transforming growth factor- $\beta 1$ mediates suppression in the tumor microenvironment. Clin Cancer Res. 2007;13(15 Pt 1):4345-54.

7. von Boehmer H. Mechanisms of suppression by suppressor $\mathrm{T}$ cells. Nature immunology. 2005;6(4):338-334.

8. Mora JR, Iwata M, Eksteen B, Song S-Y, Junt T, Senman B, et al. Generation of gut-homing IgAsecreting B cells by intestinal dendritic cells. Science. 2006;314(5802):1157-60.

9. Schwartz DP, Buckley RH. Serum IgE concentrations and skin reactivity to anti-IgE antibody in IgA-deficient patients. New England Journal of Medicine. 1971;284(10):513-7.

10. Taylor B, Norman A, Orgel H, Turner M, Stokes C, Soothill J. Transient IgA deficiency and pathogenesis of infantile atopy. Lancet. 1973;302(7821):111-3.

11. Denburg JA, Sehmi R, Upham J, Wood L, Gauvreau G, O'Byrne P. Regulation of IL -5 and IL-5 Receptor Expression in the Bone Marrow of
Allergic Asthmatics. Int Arch Allergy Immunol. 1999;118(2-4):101-3.

12.Denburg JA, Sehmi R, Upham J. Regulation of IL-5 receptor on eosinophil progenitors in allergic inflammation: role of retinoic acid. Int Arch Allergy Immunol. 2001;124(1-3):246-8.

13.Tokuyama H, Tokuyama Y, Nakanishi K. Retinoids inhibit IL-4-dependent IgE and IgG1 production by LPS-stimulated murine splenic B cells. Cellular immunology. 1995;162(1):153-158. 14. Ross AC. Vitamin A and retinoic acid in T cellrelated immunity. Am J Clin Nutr. 2012;96(5):1166S-1172S.

15.Cantorna MT, Nashold FE, Hayes CE. Vitamin A deficiency results in a priming environment conducive for Th1 cell development. Eur J Immunol. 1995;25(6):1673-9.

16. Son H-L, Park H-R, Park Y-J, Kim S-W. Effect of retinoic acid in a mouse model of allergic rhinitis. Allergy Asthma Immunol Res. 2015;7(6):590-598.

17.Okubo K, Kurono Y, Fujieda S, Ogino S, Uchio $\mathrm{E}$, Odajima $\mathrm{H}$, et al. Japanese guideline for allergic rhinitis. Allergology International. 2011;60(2):171-89.

18.Karagiannidis C, Akdis M, Holopainen P, Woolley NJ, Hense G, Rückert B, et al. Glucocorticoids upregulate FOXP3 expression and regulatory $\mathrm{T}$ cells in asthma. $\mathrm{J}$ Allergy Clin Immunol. 2004;114(6):1425-33.

19.Ling EM, Smith T, Nguyen XD, Pridgeon C, Dallman M, Arbery J, et al. Relation of CD4+ $\mathrm{CD} 25+$ regulatory T-cell suppression of allergendriven T-cell activation to atopic status and expression of allergic disease. Lancet. 2004;363(9409):608-15.

20.Grindebacke H, Wing K, Andersson AC, Suri-Payer E, Rak S, Rudin A. Defective suppression of Th2 cytokines by CD4+ CD25+ regulatory $\mathrm{T}$ cells in birch allergics during birch pollen season. Clin Exp Allergy. 2004;34(9):136472.

21.Ruhl R, Garcia A, Schweigert FJ, Worm M. Modulation of cytokine production by low and high retinoid diets in ovalbumin-sensitized mice. Int J Vitam Nutr Res. 2004;74(4):279-84. 
22.Iwata M, Eshima Y, Kagechika H. Retinoic acids exert direct effects on T cells to suppress Th1 development and enhance Th2 development via retinoic acid receptors. Int Immunol. 2003;15(8):1017-25.

23. Matheu V, Barrios Y, Berggrd K, Baeza M, Zubeldia J, Back O, Issazadeh-Navikas S. Influence of retinoic acid in allergic inflammation. Annals of Allergy Asthma \& Immunology 98: 1. A83-A83.

24.Milner JD, Stein DM, McCarter R, Moon RY. Early infant multivitamin supplementation is associated with increased risk for food allergy and asthma. Pediatrics. 2004;114(1):27-32.

25. Kull I, Bergström A, Melén E, Lilja G, van Hage M, Pershagen $G$, et al. Early-life supplementation of vitamins $\mathrm{A}$ and $\mathrm{D}$, in watersoluble form or in peanut oil, and allergic diseases during childhood. J Allergy Clin Immunol. 2006;118(6):1299-304.

26. Lúðvíksson $\mathrm{B}$, Arason $\mathrm{G}$, Thorarensen $\mathrm{O}$, Ardal B, Valdimarsson H. Allergic diseases and asthma in relation to serum immunoglobulins and salivary immunoglobulin A in pre-school children: a follow-up community-based study. Clin Exp Allergy. 2005;35(1):64-9.

27. Calvo M, Grob K, Marín F, Bertoglio J, Neira $\mathrm{J}$, Arellano P, et al. Evaluation of secretory IgA childhood respiratory diseases. Allergol Immunopathol (Madr). 1988;16(3):157-61.

28. Payette K, Weiss N. Salivary IgA levels in atopic children. Annals of allergy. 1977;39(5):328-31.

29. Van Asperen P, Gleeson M, Kemp A, Cripps A, Geraghty S, Mellis C, et al. The relationship between atopy and salivary IgA deficiency in infancy. Clin Exp Immunol. 1985;62(3):753-757.

30. Stokes C, Taylor B, Turner M. Association of house-dust and grass-pollen allergies with specific IgA antibody deficiency. The Lancet. 1974;304(7879):485-488.

31. Gleeson M, Clancy RL, Hensley MJ, Cripps AW, Henry RL, Wlodarczyk JH, et al. Development of bronchial hyperreactivity following transient absence of salivary IgA. Am J Respir Crit Care Med. 1996;153(6 Pt 1):1785-9.

32. Martino D, Currie H, Taylor A, Conway P, Prescott S. Relationship between early intestinal colonization, mucosal immunoglobulin A production and systemic immune development. Clin Exp Allergy. 2008;38(1):69-78.

33. Brown MA, Hural J. Functions of IL-4 and Control of Its Expression. Crit Rev Immunol. 1997;17(1):1-32.

34. Yano N, Endoh M, Miyazaki M, Yamauchi F, Nomoto Y, Sakai H. Altered production of $\mathrm{IgE}$ and IgA induced by IL-4 in peripheral blood mononuclear cells from patients with IgA nephropathy. Clin Exp Immunol. 1992;88(2):295300.

35.Böttcher $\mathrm{M}$, Häggström $\mathrm{P}$, Björksten $\mathrm{B}$, Jenmalm M. Total and allergen-specific immunoglobulin A levels in saliva in relation to the development of allergy in infants up to 2 years of age. Clin Exp Allergy. 2002;32(9):1293-8.

36. Perrier C, Thierry AC, Mercenier A, Corthesy B. Allergen-specific antibody and cytokine responses, mast cell reactivity and intestinal permeability upon oral challenge of sensitized and tolerized mice. Clin Exp Allergy. 2010;40(1):15362.

37. Ciprandi G, Vizzaccaro A, Cirillo I, Tosca M, Massolo A, Passalacqua G. Nasal eosinophils display the best correlation with symptoms, pulmonary function and inflammation in allergic rhinitis. Int Arch Allergy Immunol. 2005;136(3):266-72.

38. Chowdary VS, Vinaykumar EC, Rao JJ, Rao $\mathrm{R}$, Babu KR, Rangamani V. A study on serum IgE and eosinophils in respiratory allergy patients. Indian J Allergy Asthma Immunol. 2003;17(1):214.

39.Krouse JH, Chadwick SJ, Gordon BR, Derebery MJ. Allergy and immunology: an otolaryngic approach: Lippincott-Williams \& Wilkins Philadelphia; 2002.

40.Sybilski AJ, Raciborski F, Lipiec A, Tomaszewska A, Lusawa A, Furmanczyk K, et al. Obesity--a risk factor for asthma, but not for atopic dermatitis, allergic rhinitis and sensitization. Public Health Nutr. 2015;18(3):530-6.

41. Baumann S, Lorentz A. Obesity - a promoter of allergy?. Int Arch Allergy Immunol. 2013;162(3):205-13.

42. Lei Y, Yang H, Zhen L. Obesity is a risk factor for allergic rhinitis in children of Wuhan (China). Asia Pac Allergy. 2016;6(2):101-104. 
43. Saadeh D, Salameh P, Caillaud D, Charpin D, de Blay F, Kopferschmitt C, et al. High body mass index and allergies in schoolchildren: the French six cities study. BMJ Open Respir Res. 2014;1(1):e000054.

44. Han YY, Forno E, Gogna M, Celedon JC. Obesity and rhinitis in a nationwide study of children and adults in the United States. J Allergy Clin Immunol. 2016;137(5):1460-5.

45. Yao TC, Ou LS, Yeh KW, Lee WI, Chen LC, Huang JL. Associations of age, gender, and BMI with prevalence of allergic diseases in children: PATCH study. J Asthma. 2011;48(5):503-10. 